\title{
Study on some hemato-biochemical changes associated with Babesia Bovine in cattle of El-Wisata -Libya
}

\author{
Nagia A. S.Abdalsalam*, Safia Hazawy and Hamzah Othman \\ Department of Clinical Pathology, Faculty of Veterinary Medicine, Omar Al-Mukhtar University, \\ Al-Bayda, Libya
}

Received: 04 July 2019/ Accepted: 30 December 2019

Doi: https://doi.org/10.54172/mjsc.v34i4.200

\begin{abstract}
Bovine Babesiosis is a tick-borne disease of cattle caused by haemoparasite of the genus Babesia. This parasite is responsible for considerable losses due to mortality, weight loss, and reduction in milk besides the cost of treatments. This study aimed to study the effect of Babesia on some hematological and biochemical parameters on cattle in farms of El-Wisata in the El-Gabal El-Akhdar area. Twenty-three of crossbred cattle of 3-8 years old were examined. Giemsa stained thin blood smears from the ear vain of all 23 cases of crossbred cattle for microscopic examination to diagnose the parasite in the blood and divided the animals into two groups (7 non-infected group (30.5\%) and 16 infested group $(69.5 \%))$, as well as two blood tubes (with EDTA) from the jugular vein of all cases were collected for hematological analysis and (without EDTA) for biochemical analysis. The results of the haemato-biochemical studies showed a significant reduction in the levels of RBC, PCV, Hb, MCH, $\mathrm{MCV}, \mathrm{TP}, \mathrm{Ca}+$ and $\mathrm{Na}+$ with a significant increase in $\mathrm{WBC}$ and $\mathrm{K}-$ levels in the crossbred cattle infected group. The infected cases marked the clinical-pathological symptoms like fever $\left(41 \mathrm{C}^{\circ}\right)$, Anorexia, depression, weakness, pale mucous membrane, weight loss, hemoglobin urea, decrease in milk and death within a few days.
\end{abstract}

Keywords: Babesia Bovine, crossbred cattle, Haemato-biochemical Alterations.

\section{INTRODUCTION}

Cattle play an essential role in our life as they are the main source of milk and meat. The cattle's health has deteriorated due to parasitic diseases in general and blood parasites in particular(Talkhan et al., 2010) Bovine Babesiosis is a parasitic disease caused by an intraerythrocytic protozoan of the genus Babesia (Alvarez et al., 2019). It infects a wide range of domestic and wild animals with a main impact on cattle. This disease has been distributed in the world (Bock et al., 2004; Ristic \& Levy, 1981). Babesia is the second most commonplace parasite situated within the blood of mammals after trypanosomes (ElHamed et al., 2016). In addition, some species of Babesia are zoonotic and affect human health (Talkhan et al., 2010) It is still representing a serious trouble in tropical and subtropical countries (Hussein et al., 2007), It leads to lowering the productive performance of the affected animals (Zulfiqar et al., 2012).It is an important disease in Middle East countries because it sometimes occurs in acute forms with serious recognized clinical alteration which affects the production of animals (Talkhan et al., 2010). In Libya, the prevalence in Tripoli was $12.9 \%$ (El Maghrabi et al., 2008) El-Gabal El-Akhdar was $29.86 \%$ (Bulabiad, 2013). 16.74\% The most common species that cause infection on cattle are Babesia bigemina, Babesia divergens, Babesia bovis (Adham et al., 2009) Babesia species cause acute disease by two principle methods i.e hemolysis and circulatory disturbance (Mohammed \& Elshahawy, 2017).

Clinically, this disease has been characterized by high fever $\left(40-41.6^{\circ} \mathrm{C}\right)$, anorexia, weight

*Corresponding Author: Nagia A. S.Abdalsalam almabrouk20072008@yahoo.com Department of Clinical Pathology, Faculty of Veterinary Medicine, Omar Al-Mukhtar University, Al-Bayda, Libya 
loss, ruminal atony, dyspnea, and hemoglobinuria (MM, 2017). Some studies have reported that the calves up to 9-12 months of age are generally resistant to such diseases due to inverse age resistance, but the clinical symptoms in neonatal calves were inability to suckle. Babesia causes red water urine (haemoglobinuria) or dark brown to coffee in urine color accurding to babesia stages, various degrees of jaundice from paleness in mild cases to severe yellow discoloration of the conjunctiva (Schalm, 1965) and vaginal mucous membranes in more serious cases and deep shallow respiration in sheep, goats, cattle, horses, dogs, and cats (Bal et al., 2016).

Babesia sporozoites are injected into the host by ticks and invade red blood cells (RBCs) where they transform into trophozoites that grow and divide into two pear-shaped merozoites. Babesia enters directly into red blood cells of the host (Lounsbury, 1906), the division process is then repeated. The parasite infects and destroys red blood cells, it can lead to a serious condition called hemolytic anemia (Koger, 1981). The main cause of anemia is due to intravascular hemolysis, and the rate of damage of erythrocytes and capacity of erythropoiesis. Hyperemia occurs in mucous membranes at later stages (MM, 2017). It causes a decline in erythrocyte count, packed cell volume, and hemoglobin level and serum changes may include increased potassium and reduced calcium and sodium levels (Tufani et al., 2015).

The quickly dividing parasites in the red cells create rapid damage to the erythrocytes (Pandey \& Misra, 1987) associated with hemoglobinaemia. This may cause death within a few days (Mohammed \& Elshahawy, 2017). So, the present study was designed to diagnose the disease and determine the changes in some hematological and biochemical parameters in some infested cattle with bovine Babesia in ElWisata in El-Gabal El-Akhdar area- Libya.

\section{MATERIALS AND METHODS}

Study area and period: The present study was conducted between March 2017 and January 2018. The seasons of the study included rainy (September, October, November, December, January, March, and April) and sunny (May, June, July, and August) periods. The study location was on farms of El-Wisata in El-Gabal El-Akhdar area-Libya.

Animals: A total number of twenty-three crossbred cattle, from three to eight years old, were examined and divided into two groups showing clinical signs, ticks and some haemato-biochemical effects of Babesia bovine on the two groups, naturally infected group and healthy or non-infected group.

Blood Samples: Three samples were collected from each one of all 23 cases. The first sample was a drop from ear vein to make a blood smear for microscopic examination, however, for each sample, three smears were examined very carefully so that not a single organism might escape. While the second one was serum samples for biochemical analysis of $\mathrm{TP}, \mathrm{Ca}^{+}$, $\mathrm{Na}^{+}, \mathrm{K}^{-}$and the third was blood samples for CBC Examination.

Clinical Diagnosis: All 23 cases of crossbred cattle were diagnosed by the Giemsa stained thin blood smears technique (Coles, 1986).

Hematological parameters: Approximately, 2 $\mathrm{ml}$ sample of blood was collected with EDTA anti-coagulant and was sent to the laboratory directly in an Ice Container and analyzed for hematological parameters which included hemoglobin $(\mathrm{Hb} \mathrm{g} / \mathrm{dL})$, packed cell volume (PCV \%), total erythrocyte count (RBC $\times 10^{6} / \mu \mathrm{L}$ ), total leukocyte count (WBC $\times$ $\left.10^{3} / \mu \mathrm{L}\right)$ and differential leukocyte count (Sharma et al., 2016). Mean corpuscular volume (MCV), mean corpuscular hemoglobin (MCH) and mean corpuscular hemoglobin concentration (MCHC). These hematological analyses were measured by a Complete Blood Count device $\mathrm{CBC}$ in Laboratory Diagnosis.

Biochemical assays: The collected blood samples were kept about 10 minutes at room 
temperature. After centrifugation at $3000 \mathrm{rpm}$ for 15 minutes using Thermo Scientific Centrifuge, serum was placed in a $1.5 \mathrm{ml}$ Eppendorf tube and kept at $-20^{\circ} \mathrm{C}$ until it was analyzed. Total serum protein (TP) was estimated by the Biuret method forming a violet-colored copperprotein complex having maximum absorption at $550 \mathrm{~nm}$. Calcium $\left(\mathrm{Ca}^{+}\right)$, Sodium $\left(\mathrm{Na}^{+}\right)$and potassium $\left(\mathrm{K}^{-}\right)$levels of serum samples were estimated using commercial kits (Wharton \& McCarty, 1972).

Statistical analysis: Data were presented as mean \pm standard error (S.E.). Data were analyzed using an independent sample T-test. P values $\leq 0.05$ were considered to be statistically significant (SPSS Version 19) (Snedecor \& Cochran, 1994).

\section{RESULTS}

Clinical Findings: Cattle infected with B. bovis demonstrated characteristic clinical signs of babesiosis. Briefly, a high rise in body temperature (40-41.6), body condition is thin, pale and empty episcleral blood vessels were anemic. The clinical severity ranged from paleness in mild cases to severe yellow discoloration in more advanced stages of the infected cases, red water urine (haemoglobinuria) or dark brown to coffee in urine color according to Babesia stages, severe clinical manifestation and accelerated heart and respiratory rates. Some cases showed nervous manifestations in advanced stages. Different degrees of tick infestations were present intermandibular space, around groins, horns and ears .

Hematological Findings: $16(69.5 \%)$ out of 23 cases showed the presence of the parasite Babesia from ear vain and seven cases were negative 7 (30.5\%).

Hematological parameters: The mean values of Red Blood Cells (RBCs $10^{6} / \mu 1$ ), hemoglobin concentration $\mathrm{Hb}(\mathrm{g} / \mathrm{dl}$, Packed cell volume (PCV \%), White Blood Cells (WBCs 103/ $\mu 1$ ), differential leucocytes count DLC \%, Mean Corpuscular Volume (MCV fl), and Mean corpuscular hemoglobin ( $\mathrm{MCH}$ pg) are listed in Table 1.

Table:(1). The results of the hematological parameters of infested/non-infested.

\begin{tabular}{|c|c|c|}
\hline \multirow{2}{*}{$\begin{array}{c}\text { Haematological } \\
\text { Parameter }\end{array}$} & \multicolumn{2}{|c|}{$\overline{\mathrm{MEAN}} \pm \mathrm{SE}$} \\
\hline & Infected group & Non infected group \\
\hline $\mathrm{Hb} \mathrm{g} / \mathrm{dl}$ & $5.98 \pm 0.23^{b}$ & $12.03 \pm 0.34^{\mathrm{a}}$ \\
\hline $\mathrm{WBC} 10^{3} / \mu \mathrm{l}$ & $7.022 \pm 0.42^{\mathrm{a}}$ & $5.30 \pm 0.55^{\mathrm{b}}$ \\
\hline Monocyte \% & $10.003 \pm 0.78^{\mathrm{a}}$ & $3.50 \pm 0.31^{\mathrm{b}}$ \\
\hline Eosinophils \% & $13.87 \pm 0.88^{\mathrm{a}}$ & $5.13 \pm 0.09^{\mathrm{b}}$ \\
\hline Neutrophils \% & $16.947 \pm 0.12^{\mathrm{b}}$ & $31.32 \pm 0.90^{\mathrm{a}}$ \\
\hline Lymphocytes \% & $59.18 \pm 0.21^{\mathrm{a}}$ & $60.05 \pm 0.23^{b}$ \\
\hline $\mathrm{RBC} 10^{6} / \mu \mathrm{l}$ & $4.32 \pm 0.18^{\mathrm{b}}$ & $6.94 \pm 0.20^{\mathrm{a}}$ \\
\hline $\mathrm{PCV} \%$ & $19.12 \pm 0.63^{b}$ & $31.16 \pm 0.41^{\mathrm{a}}$ \\
\hline MCV fl & $39.01 \pm 1.02^{b}$ & $44.26 \pm 0.11^{\mathrm{a}}$ \\
\hline $\mathrm{MCH}$ pg & $12.31 \pm 0.35^{\mathrm{b}}$ & $15.67 \pm 0.57^{\mathrm{a}}$ \\
\hline
\end{tabular}

*small letters mean there is a significant different between two groups.

Briefly, the important findings can be summarized as follows; there was a significant reduction $(\mathrm{P}<0.05)$ in the mean values \pm standard error of RBC, PCV, Hb, MCH, MCV and Lymphocyte with a significant increase $(\mathrm{P}<0.05)$ in $\mathrm{WBC}$, and DLC. Therefore, it is clear that there are significant differences in the hematological parameters between the $B$. bovine infected group and the control one.

Biochemical parameters: The mean values of Total Protein (TP), Calcium $\left(\mathrm{Ca}^{+}\right)$, Potassium $\mathrm{K}^{-}$and Sodium $\left(\mathrm{N}^{+}\right)$of infected and control groups are listed in Table 2.

Table:(2). The results of the Biochemical parameters of infested/non-infested cattle

\begin{tabular}{|c|c|c|}
\hline \multirow{2}{*}{$\begin{array}{l}\text { Biochemical } \\
\text { Parameter }\end{array}$} & \multicolumn{2}{|c|}{$\mathrm{MEA} \pm \mathrm{SE}$} \\
\hline & Infected group & Non Infected group \\
\hline $\mathrm{TP} \mathrm{g} / \mathrm{dl}$ & $5.49 \pm 0.23^{b}$ & $7.455 \pm 0.30^{\mathrm{a}}$ \\
\hline $\mathrm{Ca}+\mathrm{mg} / \mathrm{dl}$ & $7.22 \pm 0.24^{\mathrm{b}}$ & $9.55 \pm 0.55^{\mathrm{a}}$ \\
\hline $\mathrm{K}-\mathrm{mmol} / \mathrm{l}$ & $4.62 \pm 0.41^{\mathrm{a}}$ & $4.1 \pm 0.16^{\mathrm{b}}$ \\
\hline $\mathrm{Na}+\mathrm{mmol} / 1$ & $119.13 \pm 1.52^{b}$ & $146.33 \pm 2.81^{\mathrm{a}}$ \\
\hline
\end{tabular}

\begin{tabular}{lll}
$\mathrm{Na}+\mathrm{mmol} / 1$ & $119.13 \pm 1.52^{\mathrm{b}}$ & $146.33 \pm 2.81^{\mathrm{a}}$ \\
\hline
\end{tabular}

*small letters mean there is a significant different between two groups. A comparison of serum biochemical examination of parasite positive and negative blood samples from cattle showed a significant increase $(\mathrm{P}<0.05)$ in potassium level $\mathrm{K}$-. However, a significant decrease $(\mathrm{P}<0.05)$ was 
recorded in total protein $\mathrm{TP}$, calcium, and sodium levels.

\section{DISCUSSION}

In the present study, Babesia infection was confirmed by light microscopy examination in farms of El-Wisata in El-Gabal El-Akhdar area. The observed clinical findings in cattle with Babesia Bovine have shown that animals suffering from a lot of symptoms such as high temperature (40-41.6), pale mucous membranes, thin body, dark brown to coffee urine in color, increased heart and respiratory rates. These findings were in agreement with (Bal et al., 2016; Fujinaga, 1981; Georgi et al., 1990).

The clinical findings Microscopic examination of Giemsa stained blood smear of all 23 cases of crossbred cattle revealed that 16 cases (69.5\%) had parasites in the blood and these cases were named as naturally infested group and 7 cases had normal blood (30.5\%) and were called as the control group.(Samad et al., 1989) supported this view. (Karim et al., 2012) also recorded Babesia organisms through Giemsa's staining of blood smear. However, reports of (Banerjee et al., 1983) were discordant with higher prevalence $(14.53 \%)$ of subclinical infections.

The clinical findings can be attributed to the multiplication of organisms in peripheral vessels and consequence intravascular hemolysis (Rajendran \& Hafeez, 2003). The hemolysis was due to anemia and hemoglobinuria (Rani et al., 2010). Several factors contribute to anemia in babesiosis, such as a decrease in the amount of erythrocytes hemoglobin concentration (Hussein et al., 2007). The Hematological principles were adversely affected in positive cases (Ananda et al., 2009). Table 1 shows a significant reduction $(\mathrm{P}<0.05)$ in the mean values of $\mathrm{RBC}$, $\mathrm{PCV}, \mathrm{Hb}, \mathrm{MCH}, \mathrm{MCV}$, and neutrophils as a result of an immune response to Babesia infection (Mahmoud \& Abou-Zeina, 2008), with a significant increase $(\mathrm{P}<0.05)$ in $\mathrm{WBC}$, (C) 2019 The Author(s). This open access article is distributed under a CC BY-NC 4.0 license. ISSN: online 2617-2186 print 2617-2178 monocytes, and Eosinophils in comparison with healthy control. Babesiosis causes normocytic normochromic anemia in cattle which could be attributed to intravascular haemolysis of red blood cells, and this is supported by (Guglielmone et al., 1996; Pandey \& Misra, 1987) agrees with significant increases in WBC, Eosinophils and monocytes associated with a significant decrease $(\mathrm{P}<0.005)$ in neutrophils. This could be explained as the breakdown of RBC by Babesia stimulates the phagocytic cells such as lymphocytes and monocytes to clean up the body from the toxic remnants of ruptured red blood cells. Babesia infection leads to the stimulation of the body defense mechanism to produce antibodies against the Babesia antigen. (Court et al., 2001) mentioned that the significant increase in monocytes in primary Babesia infection could be attributed to their role as active mediators in the innate immune response. The serum of Babesiosis infected cattle showed a decrease in calcium levels, increase in potassium levels and reduced sodium levels. This finding agrees with (MM, 2017).

This occurs because Babesia can cause degeneration and necrosis in kidney convoluted tubules (Salem et al., 2016) There was a highly significant decrease in total protein in the serum of infected clinical cases. This could have occurred because Babesia can cause disruption in liver function that leads to decrease production from the liver due to direct and indirect effect of the parasite, digestive disturbance (diarrhea), loss of appetite and high fever (Atif et al., 2012; Salem et al., 2016) who recorded that with low levels of parasitemia, Babesia may not be found on microscopic examination. (Ananda et al., 2009; Chowdhury et al., 2006) documented that more attention in the management of crossbred cattle gives less chance of pre-exposure of vectors and develops no or less immunity, resulting in the frequent occurrence of such diseases.

\section{CONCLUSION}


The results obtained from this study could be useful as basic information for a further advanced epidemiological study and formulation of control measures of tick-borne diseases. Further investigation using modern serological and molecular techniques with a large number of samples is recommended especially in another part of the country in order to further establish the effects of tick infestation in cattle of other parts of Libya and management of the disease.

\section{REFERENCES}

Adham, F., Abd-El-Samie, E., Gabre, R., \& Hussein, H. E. (2009). Detection of tick blood parasites in Egypt using PCR assay I-Babesia bovis and Babesia bigemina. Parasitology research, 105(3), 721.

Alvarez, J. A., Rojas, C., \& Figueroa, J. V. (2019). Diagnostic Tools for the Identification of Babesia sp. in Persistently Infected Cattle. Pathogens, 8(3), 143.

Ananda, K., D'Souza, P. E., \& Puttalakshmamma, G. (2009). Prevalence of Haemoprotozoan diseases in crossbred cattle in Banglore north. Veterinary World, 2(1), 15.

Atif, F. A., Khan, M. S., Iqbal, H. J., Arshad, G. M., Ashraf, E., \& Ullah, S. (2012). Prevalence of Anaplasma marginale, Babesia bigemina and Theileria annulata infections among cattle in Sargodha District, Pakistan. Afr. J. Agric. Res, 7(22), 3302.

Bal, M. S., Mahajan, V., Filia, G., Kaur, P., \& Singh, A. (2016). Diagnosis and management of bovine babesiosis outbreaks in cattle in Punjab state. Veterinary World, 9(12), 1370.
Banerjee, D., Prasad, K., \& Samad, M. (1983). Seroprevalence of Babesia bigemina infection in cattle of India and Bangladesh. Indian journal of animal sciences.

Bock, R., Jackson, L., De Vos, A., \& Jorgensen, W. (2004). Babesiosis of cattle. Parasitology, 129(S1), S247S269.

Bulabiad A. A. (2013) Studies on blood parasites affecting farm animals in $\mathrm{Al}$ Jabal Al Akhdar Libya. MS Dissertation Alexandria University, Egypt.99

Chowdhury, S., Hossain, M., Barua, S., \& Islam, S. (2006). Occurrence of common blood parasites of cattle in Sirajgonj sadar area of Bangladesh. Bangladesh Journal of Veterinary Medicine, 4(2), 143-145.

Coles, E. (1986). Veterinary clinical pathology. WB Saunders co. Philadelphia. London. Toronto.

Court, R., Jackson, L., \& Lee, R. (2001). Elevated anti-parasitic activity in peripheral blood monocytes and neutrophils of cattle infected with Babesia bovis. International journal for parasitology, 31(1), 29-37.

El Maghrabi, A. A., ELsayed, I. H., Hassaneen, A.S., Nisreen. Ezeldin (2008). Incidence of Theileriosis, Babesiosis and Anaplasmosis in cattle in Tripoli Libya. The Veterinary Medical JournalGiza 56(.2):71-82

El-Hamed, H. A. A., Salem, S. M., \& Ibrahim, H. N. (2016). Haemato-biochemical Alterations in Cattle Suffering from Anaemia and Their Effect on Quality of Some Meat. 
Fujinaga, T. (1981). Bovine babesiosis in Japan: Clinical and clinico-pathological studies on cattle experimentally infected with Babesia ovata. (The Japanese Journal of Veterinary Science), 43(6), 803-813.

Georgi, J., Georgi, M., \& Theodorides, V. (1990). Parasitology for Veterinarians. 5 th. WB Sounders Company.

Guglielmone, A., Gaido, A., \& Mangold, A. (1996). Light microscopy diagnosis of Babesia and Theileria in haemolymph of artificially infected Boophilus microplus engorged female ticks. Vet. Parasitology, 61, 15-20.

Hussein, A., Mohammed, N., \& Mohammed, H. (2007). Theileriosis and babesiosis in cattle: haemogram and some biochemical parameters. Proceedings of XIII International Congress of International Society of Animal Hygiene,

Karim, M., Rima, U., Hossain, M., Habib, M., Islam, M., Hossain, M., \& Khan, M. (2012). Adoption of Polymerase Chain Reaction Techniques for the Detection and Differentiation of Babesiosis, Anaplasmosis and Theileriosis in Clinically Infected and Slaughtered Cattle.

Koger, M. (1981). Characteristics of Types and Breeds of Cattle in the Tropics. In Diseases of cattle in the tropics (pp. 322). Springer.

Lounsbury, C. P. (1906). Transmisson of African Coast Fever.

Mahmoud, M. S., \& Abou-Zeina, H. A. (2008). Current state in the serological diagnosis of babesiosis and haematological changes in splenectomised buffaloes. Global Veterinaria, 2(5), 271-281.

MM, M. S. (2017). Studies of Naturally Infected Babesiosis and Its Effect on Some Hematological and Biochemical Parameters in Cattle in Qena, Egypt.

Mohammed, E., \& Elshahawy, I. (2017). The Current Prevalence of Bovine Babesiosis and Theileriosis Infection in Egypt. Clin Med Images Int J, 1(1), 00004.

Pandey, N., \& Misra, S. (1987). Hematological And Biochemical Response To Hemolytic-Anemia Of Clinical Babesiosis In Cattle And Therapy. Indian Veterinary Journal, 64(10), 882886.

Rajendran, C., \& Hafeez, M. (2003). Haematobiochemical changes and efficacy of different acaricides in crossbred animals. Indian Journal of Animal Sciences (India).

Rani, N. L., Sreedevi, C., Annapurna, P., \& Kumar, K. (2010). Clinical management and haemato-biochemical changes in babesiosis in buffaloes. Buffalo Bull, 29(2), 92-94.

Ristic, M., \& Levy, M. (1981). A new era of research toward solution of bovine babesiosis [Tick control, vaccines].

Salem, N. Y., Yehia, S. G., Farag, H. S., \& Elkhiat, M. A. (2016). Clinical, hematobiochemical alterations and oxidantantioxidant biomarkers in Babesiainfected calves. International journal of veterinary science and medicine, 4(1), $17-22$

Samad, M., Bashar, S., Shahidullah, M., \& Ahmed, M. (1989). Prevalence of haemoprotozoan parasites in cattle of 
Bangladesh. Indian veterinary medical journal.

Schalm, O. (1965). Veterinary Heamatology, 2nd edt. Ballere, London.

Sharma, A., Singla, L. D., Ashuma, B. K. B., \& Kaur, P. (2016). Clinicopathobiochemical alterations associated with subclinical babesiosis in dairy animals. Journal of arthropod-borne diseases, 10(2), 258.

Snedecor, G., \& Cochran, W. (1994). Statistical Methods'.(The Iowa State University Press: Ames, Iowa, USA).

Talkhan, O., Radwan, M., \& Ali, M. (2010). Cattle babesiosis and associated biochemical alteration in Kalubyia Governorate. Nat Sci, 12, 24-27.

Tufani, N., Fazili, M., Malik, H., Beigh, S., \& Dar, K. H. (2015). Clinico haematological Profile and therapeutic management of acute babesiosis in a Holstein-friesian crossbred cow. Veterinary Clinical Science, 3(3), 1114.

Wharton, D., \& McCarty, R. (1972). Enzymes: partial purification and some kinetic properties of an acid phosphatase from wheat germ. Experiments and Methods in Biochemistry. Wharton, DC, and RE McCarty, ed. The Macmillan Company, New York, 220-245.

Zulfiqar, S., Shahnawaz, S., Ali, M., Bhutta, A. M., Iqbal, S., Hayat, S., Qadir, S., Latif, M., Kiran, N., \& Saeed, A. (2012). Detection of Babesia bovis in blood samples and its effect on the hematological and serum biochemical profile in large ruminants from Southern Punjab. Asian Pacific journal of tropical biomedicine, 2(2), 104-108. 


\title{
دراسة التغيرات في مكونات الام و بعض مركبات الكيمياء الحيوية المرتبطة ببوفين البابيزيا في الابقار في الوسيطة - ليبيا
}

\author{
ناجية المبروك عبدالسلام*، صفية شعيب الهزاوي وحمزه مفتاح عامر عثمان

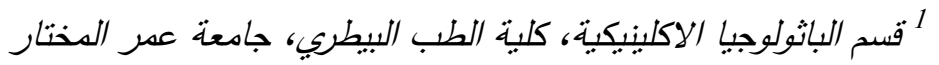

تاريخ الاستلام: 04 يوليو 2019 / تاريخ القبول: 30 ديسمبر 2019 https://doi.org/10.54172/mjsc.v34i4.200:Doi

المستخلص: بوفين البابيزيا هو مرض ينقله القراد للماثية يتسبب عن طفيل الدم من جنس البابيزيا. هذا الطفيل مسؤول عن خسائر اقتصادية كبيرة ناجمة عن الوفيات، وفقدان الوزن وانخفاض إنتاج الحليب بالإضافة إلى نكلفة العلاج. هدف هذه الدراسة

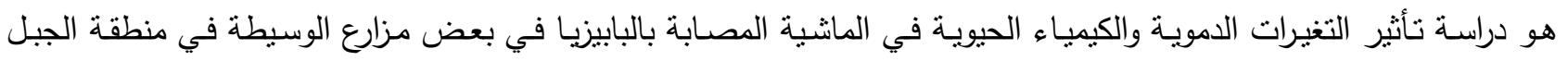

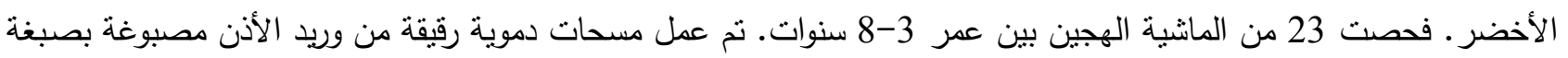
قيمزا من جميع الحالات ثم الفحص مجهرياً للكشف عن الطفيل، ومن خلال هذا الفحص قسمت إلى مجموعنين 16(59.5\%) مصابة و7(30.5\%) غير مصابة. وكذلك اجري سحب إثتين من أنابيب الدم من الوريد الوداجي في أنابيب تحتوي على مانع

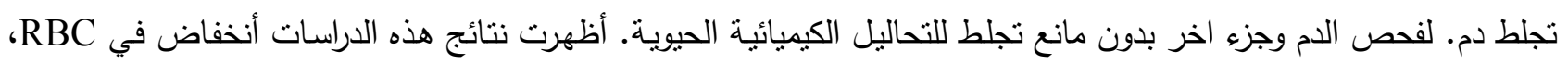

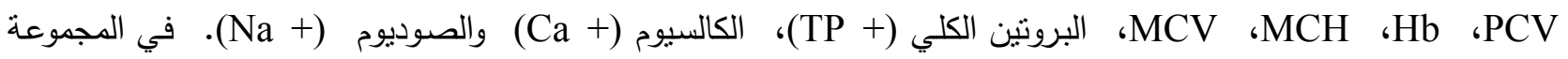
المصابة مقارنة بالسليمة مع زيادة ملحوظة في مستويات WBC و (K-) البوتاسيوم. تمبزت الحالات المصابة بالأعراض المرضية

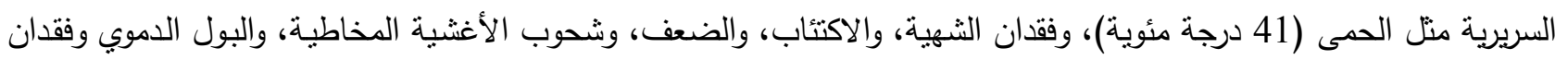
الوزن، وأنخفاض الحليب والموت في غضون بضعة أيام. الكلمات المفتاحية : بوفين البابيزيا، الأبقار الهجينة، تغيرات دموية ومركبات كيمياء حيوية. 